\title{
Climate change scenario analysis for Baro-Akobo river basin, Southwestern Ethiopia
}

\author{
Teressa Negassa Muleta* (1)
}

\begin{abstract}
Background: Several water resources projects are under planning and implementation in the Baro-Akobo basin. Currently, the planning and management of these projects is relied on historical data. So far, hardly any study has addressed water resources management and adaptation measures in the face of changing water balances due to climate change in the basin. The main bottleneck to this has been lack of future climate change scenario base data over the basin. The current study is aimed at developing future climate change scenario for the basin. To this end, Regional Climate Model (RCM) downscaled data for A1B emission scenario was employed and bias corrected at basin level using observed data. Future climate change scenario was developed using the bias corrected RCM output data with the basic objective of producing baseline data for sustainable water resources development and management in the basin.

Result: The projected future climate shows an increasing trend for both maximum and minimum temperatures; however, for the case of precipitation it does not manifest a systematic increasing or decreasing trend in the next century. The projected mean annual temperature increases from the baseline period by an amount of $1{ }^{\circ} \mathrm{C}$ and $3.5^{\circ} \mathrm{C}$ respectively, in 2040s and 2090s. Similarly, evapotranspiration has been found to increase to an extent of $25 \%$ over the basin. The precipitation is predicted to experience a mean annual decrease of $1.8 \%$ in $2040 \mathrm{~s}$ and an increase of $1.8 \%$ in 2090s over the basin for the A1B emission scenario.

Conclusion: The study resulted in a considerable future change in climatic variables (temperature, precipitation, and evapotranspiration) on the monthly and seasonal basis. These have an implication on hydrologic extremes-drought and flooding, and demands dynamic water resources management. Hence the study gives a valuable base information for water resources planning and managers, particularly for modeling reservoir inflow-climate change relations, to adapt reservoir operation rules to the real-time changing climate.
\end{abstract}

Keywords: A1B emission scenario, Baro-Akobo River Basin, Bias Correction, Climate change scenario, General circulation model, Regional climate model

\section{Background}

The planning and management of basin scale water resources systems has historically relied on assuming stationary hydrologic conditions. This approach assumes that past hydrologic conditions are sufficient to guide the future operation and planning of water resources systems

*Correspondence: teressa.muleta@emk.bme.hu

Department of Sanitary and Environmental Engineering, Budapest

University of Technology and Economics, Budapest, Hungary and infrastructures. This assumption is nowadays threatened by climate change and the notion that both climate and hydrology will evolve in the future. Water resource planning based on the concept of a stationary climate is increasingly considered inadequate for sustainable water resources management (Xueping et al. 2018; Mohamed 2015; Luca et al. 2020). According to the Series Assessment Reports of the Intergovernmental Panel on Climate Change (IPCC 2007) and many other studies, warming of 
the climate system is unequivocal, as is now evident from observations of increases in global average air and ocean temperatures, widespread melting of snow and ice, and rising global average sea level (Myo and Zin 2020; Rahman 2018; Safieh et al. 2020; Jose et al. 2016).

Adaptation is recognized as a critical response to the impacts of climate change. It can reduce present and future losses from climate variability and enhance climate-resilient futures (Conde et al. 2011; Cradock-Henr et al. 2018). It is a process that needs to be incorporated in the overall development planning, including the design and implementation of water resources development. Over the last few years, the literature on adaptation to climate change has expanded considerably worldwide: (Schneider et al. 2000; Brekke et al. 2009; Li et al. 2010; Raje and Mujumdar 2010; Jones 1999). However, hardly few studies have addressed water management and adaptation measures in the face of changing water balances due to climate change in Ethiopia.

\section{Climate models and downscaling}

General circulation models (GCMs) are tools designed to simulate time series of climate variables globally, accounting for effects of greenhouse gases in the atmosphere. They attempt to represent the physical processes in the atmosphere, ocean, cryosphere, and land surface. They are currently the most credible tools available for simulating the response of the global climate system to increasing greenhouse gas concentrations, and to provide estimates of climate variables (e.g., air temperature, precipitation, wind speed, pressure, etc.) on a global scale. GCMs demonstrate a significant skill at the continental and hemispheric spatial scales and incorporate a large proportion of the complexity of the global system; they are, however, inherently unable to represent local sub grid-scale features and dynamics, which are of interest to a hydrologist (Myo and Zin 2020; Conde et al. 2011; Feyissa et al. 2018).

Poor performances of GCMs at local and regional scales have led to the development of limited area models (Dickinson et al. 1989; Dinckison and Rougher 1986; Anthes et al. 1985). These techniques known as regionalization or downscaling are adopted in the literature to describe a set of techniques that relate the local and regional scale climate variables to the large scale atmospheric and oceanic forcing variables. Different regionalization techniques are available in the literatures so far: Spatial downscaling, Statistical Downscaling, and Dynamic Downscaling (Barrow et al. 1996; Conway and Hulme 1996; Smith and Pitts 1997).

For the current study, the dynamic downscaling method (regional climate model version 3.1) was employed by International Water Management Institute, Ethiopia, to downscale the GCM output data at regional level. It is a downscaling approach in which a fine, at a much smaller space-scale (e.g., $0.5^{\circ}$ by $0.5^{\circ}$ ), computational grid over a limited domain is nested within the coarse grid of a GCM (Wilby and Wigley 1997; Hewitson and Crane 1996; Cubash et al. 1996; Mearns et al. 1999).

\section{Climate and emission scenarios}

A climate scenario is a plausible representation of future climate that has been constructed for explicit use in investigating the potential impacts of anthropogenic climate change (IPCC 2001). The climate change scenarios should be assessed according to consistency with global projections, physical plausibility, applicability in impact assessments and representativeness (Hulme and Viner 1998). Climate change scenarios are tightly dependent on the emission scenarios. Future greenhouse gas (GHG) emissions are the product of very complex dynamic systems, determined by driving forces such as demographic development, socio-economic development, and technological change (Luca et al. 2020). Scenarios are alternative images of how the future might unfold and are an appropriate tool that assist in climate change analysis. According to IPCC Working Group III Special Report on Emission Scenario (SRES), four different narrative storylines were developed: (1) The A1 storyline that describes a future world of very rapid economic growth, global population that peaks in mid-century and declines thereafter and the rapid introduction of new and more efficient technologies; (2) The A2 storyline that describes a very heterogeneous world; (3) The B1 storyline that describes a convergent world with the same global population as in A1; and (4) The B2 storyline that describes a world in which the emphasis is on local solutions to economic, social, and environmental sustainability.

In the current study, the A1B storyline was chosen as it represents a balanced (moderate) future scenario in terms of the alternative energy, fossil intensive, socioeconomic, and developmental trajectories. The A1 scenario family develops into three groups that describe alternative directions of technological change in the energy system as fossil intensive (A1FI), non-fossil energy sources (A1T), or a balance across all sources (A1B). Even though it is true that the occurrence of a single storyline is highly uncertain, the A1B scenario is adopted in this paper to have single-valued climate variable predictions instead of a ranged outcome from using ensemble of extreme trajectories. These projected climatic variables can, thus, directly be used for climate change adaptation purposes like modeling climate change-runoff relationships.

So far different studies have been conducted on the climate change scenario development across the world using different models and emission scenarios. Xueping et al. (2018) with their study on Biliu River, China, has shown 
that climate emission scenarios are closely associated with temperature but not so closely associated with precipitation and runoff; Conde et al. (2011) have concluded from his study that confidence on future climate change estimations is greater for temperature than for precipitation; According to the study by Poonia and Rao (2018), rainfall trend during the last 100 years revealed that the summer monsoon rainfall has increased marginally $(<10 \%)$ in the southern and eastern parts of the Thar Desert but has already declined by $10-15 \%$ in its northwestern part India. A study in Angola by Carvalho et al. (2017) has also shown the precipitation projections to be highly variable across the region with the southern region experiencing a stronger decrease in precipitation and (Costa et al. 2019), with their study on Recife, Brazil, have emphasized the considerable decrease of rainfall in the rainy season from March to August as a contrast to an increase of rainfall in the dry months, from September to February.

Furthermore, NAPA (2007) has revealed that in Ethiopia climate variability and change in the country is mainly manifested through the variability of rainfall and temperature. The trend analysis of annual variables for (19512006) shows that rainfall remained roughly constant when averaged over the whole country while temperature shows an increasing trend all over the country. Alemayehu et al. (2016) with his study of historical climate analysis on BaroAkobo River Basin (1952-2009) has shown an increasing trend for temperature and a declining trend in case of rainfall. On contrary, the study on Blue Nile (bordering basin in the north) has projected an increasing scenario both in rainfall and temperature into the future (Roth et al. 2018). Furthermore, the study by Hany et al. (2016) has predicted a considerably increasing precipitation into future scenario on White Nile (Baro-Akobo-Sobat basin). Below is an overview of selected studies on climate change scenarios to show anomalies in rainfall change scenarios for comparison (Table 1).

\section{Statement of the problem}

Despite the numerous climate change scenario studies mentioned above, it is clearly visible that there exists inconsistency in the rainfall change scenario among different models (Table 1); spatial and temporal variation in the result from a single projection scenario (Carvalho et al. 2017; Poonia and Rao 2018); and even seasonal variation from the same study (Costa et al. 2019) is very visible in the rainfall change scenario results. This is mainly attributed to the sensitivity of the rainfall variable to local effects of particularly orographic, coastal and vegetation effects in general. Particular to the current study, the Ethiopian climate patterns show large regional differences and is also characterized by a history of climate extremes, such as drought and flood (NAPA 2007). Baro-Akobo basin exhibits distinctive bimodal rainfall pattern different from most parts of the country. There are also numerous water resources development projects under planning and implementation in the basin (Tams, Birbir A \& Birbir R, Baro-1 and Baro-2, Geba-A and Geba-R, and Genji hydropower projects; and

Table 1 Overview of previous studies on climate change scenarios

\begin{tabular}{|c|c|c|c|c|c|c|}
\hline \multirow[t]{2}{*}{ Study area } & \multirow[t]{2}{*}{ Emission scenario } & \multicolumn{2}{|l|}{ Study period } & \multicolumn{2}{|c|}{ Major findings } & \multirow[t]{2}{*}{ References } \\
\hline & & Base period & Future & $\Delta \mathrm{T}\left({ }^{\circ} \mathrm{C}\right)$ & $\Delta \mathrm{P}(\%)$ & \\
\hline \multirow[t]{2}{*}{ Biliu River, China } & \multirow[t]{2}{*}{ Ensemble of scenarios } & \multirow[t]{2}{*}{ 1980-2004 } & $2016-2040$ & $+0.4-1.5$ & -12.2 to +21.8 & \multirow[t]{2}{*}{ Xueping et al. (2018) } \\
\hline & & & $2041-2065$ & $+0.68-3.4$ & -4.1 to +2.2 & \\
\hline \multirow[t]{3}{*}{ Angola } & \multirow[t]{3}{*}{$\mathrm{RCP} 4.5$} & \multirow[t]{3}{*}{ 1958-1987 } & $2011-2040$ & +1.3 & -2.9 & \multirow[t]{3}{*}{$\begin{array}{l}\text { Carvalho et al. } \\
\text { (2017) }\end{array}$} \\
\hline & & & $2041-2070$ & +2.1 & -1.3 & \\
\hline & & & $2071-2100$ & +2.6 & -2.6 & \\
\hline \multirow[t]{2}{*}{ Dry Zone in Myanmar } & \multirow[t]{2}{*}{ RCP4.5 } & \multirow[t]{2}{*}{$1981-2005$} & $2050 s$ & $+1.5-2.2$ & +10 & \multirow[t]{2}{*}{ Myo and Zin (2020) } \\
\hline & & & $2080 s$ & $+2.0-2.6$ & +8 & \\
\hline \multirow[t]{2}{*}{ Recife city, Brazil } & \multirow[t]{2}{*}{ RCP4.5 } & \multirow[t]{2}{*}{ 1979-2000 } & $2021-2050$ & +1.0 & -5.2 & \multirow[t]{2}{*}{ Costa et al. (2019) } \\
\hline & & & $2051-2080$ & +2.0 & -15.4 & \\
\hline \multirow[t]{3}{*}{ Over Ethiopia } & \multirow[t]{3}{*}{$\mathrm{A} 1 \mathrm{~B}$} & \multirow[t]{3}{*}{$1961-1990$} & 2030 & $+0.9-1.1$ & $+1.4-4.5$ & \multirow[t]{3}{*}{ NAPA (2007) } \\
\hline & & & 2050 & $+1.7-2.1$ & $+3.1-8.4$ & \\
\hline & & & 2080 & $+2.7-3.4$ & $+5.1-13.8$ & \\
\hline \multirow[t]{3}{*}{ Over White Nile Basin } & \multirow[t]{3}{*}{$\mathrm{A} 2$} & \multirow[t]{3}{*}{ Existing condition } & 2010-2039 & +1 & -1.16 & \multirow[t]{3}{*}{ Hany et al. (2016) } \\
\hline & & & $2040-2069$ & +2.5 & -13.58 & \\
\hline & & & 2070-2099 & +3.5 & -14.77 & \\
\hline \multirow[t]{2}{*}{ Over Blue Nile } & \multirow[t]{2}{*}{$\mathrm{A} 1 \mathrm{~B}$} & \multirow[t]{2}{*}{ 1979-2013 } & $2046-2064$ & $+2.0-2.7$ & $+17.7-46$ & \multirow[t]{2}{*}{ Roth et al. (2018) } \\
\hline & & & 2081-2099 & $+2.7-3.7$ & $+27-48$ & \\
\hline
\end{tabular}


Itang and Gilo-2 irrigation projects) that will have environmental impacts on the local and downstream Nile countries-Sudan and Egypt (Tahani et al. 2013).

Therefore, it is very essential to develop basin level climate change scenario to address water resources management issues related to climate change in the basin. Unfortunately, there still lacks a full-fledged climate change scenario development at Baro-Akobo basin level. Furthermore, previous studies used to apply RCM outputs directly for climate change scenario development whereas the current study has put an effort to treat the biases in the regionally downscaled time serious data due to local factors (orographic, coastal and vegetation effects) using 30-years observed data.

\section{Objective of the study}

Climate change adaptation is fundamental to safeguarding vulnerable communities, ecosystems, and relevant climatesensitive sectors from the impacts of climate change. The key to successful adaptation is to anticipate how the climate will evolve in the future (Santosh et al. 2019). To understand the impacts of climate change on different sectors, the historical trends and future climate scenarios of different climatic parameters need to be assessed (Cradock-Henry et al. 2018).

Therefore, the main objective of this study is to develop future climate change scenario in the mid-term and longterm future periods using the $\mathrm{A} 1 \mathrm{~B}$ emission scenario. The focus is to develop bias correction factors for RCM downscaled data and projection of future climate change in terms of temperature, precipitation, and evapotranspiration for the basin using the A1B emission scenario. The developed scenario provides a basis to design adaptation pathways such as modeling the relation between reservoir inflow and climatic variables based on the likely climate change trajectories.

\section{Materials and methods Description of the study area}

The Baro-Akobo River Basin lies in the South-Western part of Ethiopia between latitudes $5^{\circ}$ and $10^{\circ}$ North and longitudes $33^{\circ}$ and $36^{\circ}$ East. In the west the basin boundary forms an international boundary with Sudan. The basin covers parts of the BenshangulGumuz, Gambella, Oromia and SNNP administrative regions. It is the second largest subbasin in the Eastern Nile basin. The Eastern Nile Basin consists four subbasins: the Baro-Akobo-Sobat (White Nile) sub-basin in the west, the Abbay (Blue Nile) sub-basin in the north, the Tekeze-Atbara sub-basin on the east and the Main Nile basin from Khartoum to the Nile delta.

With a total drainage area of about 76,000 sq km, the basin ranks number eight of the 12 major river basins in Ethiopia. Both Baro and Akobo rivers border with Sudan in their downstream sections and merge to form the Sobat River, which is a major tributary of White Nile. Neighboring river basins in Ethiopia are the Abay river basin (Blue Nile) in the north and the Omo-Gibe river basin in the south-east. The river basin has lowest elevation of about $390 \mathrm{~m}$ and highest elevation of about $3244 \mathrm{~m}$. The total mean annual flow from the river basin is estimated to be $23.6 \mathrm{BCM}$. As a result of regular flooding, the lowland areas are mainly used as pastures for grazing and no major water resources development has taken place to-date.

There are Extensive Water Resources Development Projects under planning and implementation in the basin. These include hydropower projects-Tams, Birbir A, Birbir R, Baro-1, Baro-2, Geba-A, Geba-R, and Genji hydropower projects and Irrigation projects including Itang and Gilo-2 irrigation schemes (Fig. 1).

\section{Data collection and processing Observation data}

Moreover, spatial data such as Digital Elevation Model (DEM) of $90 \mathrm{~m} * 90 \mathrm{~m}$, and Ethio-River basin shape files were collected from Ministry of Water Resource (MoWR), Ethiopia. This data is applied for location map development and areal data computations, both for observed and RCM, from point data. Different data processing techniques-data screening, trend test, stationery test, F-\& t-tests, test for relative consistency and homogeneity are all applied to ensure observation data quality.

\section{Mean-Areal Precipitation (MAP) depth computations}

There are many ways of deriving the areal precipitation over a catchment from rain gauge measurements including: Arithmetic Mean, Thiessen Polygon, Isohyetal, grid Point, Percent Normal, Hypsometric, etc. (Chow et al. 1988). Choice of methods requires judgment in consideration of quality and nature of the data, and the importance, use and required precision of the result. Accordingly, the Thiessen Polygon method was applied to determine the areal average precipitation over the basin. In this method, weights are given to all the measuring gauges based on their areal coverage of the watershed, thus eliminating the discrepancies in their spacing over the basin. HEC-GeoHMS utility of ArcGIS is employed for construction of Thiessen Polygons and assigning gage weight. Similar procedure is followed to calculate other basin areal meteorological data (e.g., ETo) and areal data of RCM GCPs meteorological data.The areal rainfall $\bar{R}$ is given by:

$$
\overline{\mathbf{R}}=\sum_{\mathbf{i}=1}^{\mathbf{n}} \frac{\mathbf{a}_{\mathbf{i}} \mathbf{R}_{\mathbf{i}}}{\mathbf{A}}=\sum_{\mathbf{i}=1}^{\mathbf{n}} \mathbf{w}_{\mathbf{i}} \mathbf{R}_{\mathbf{i}}
$$




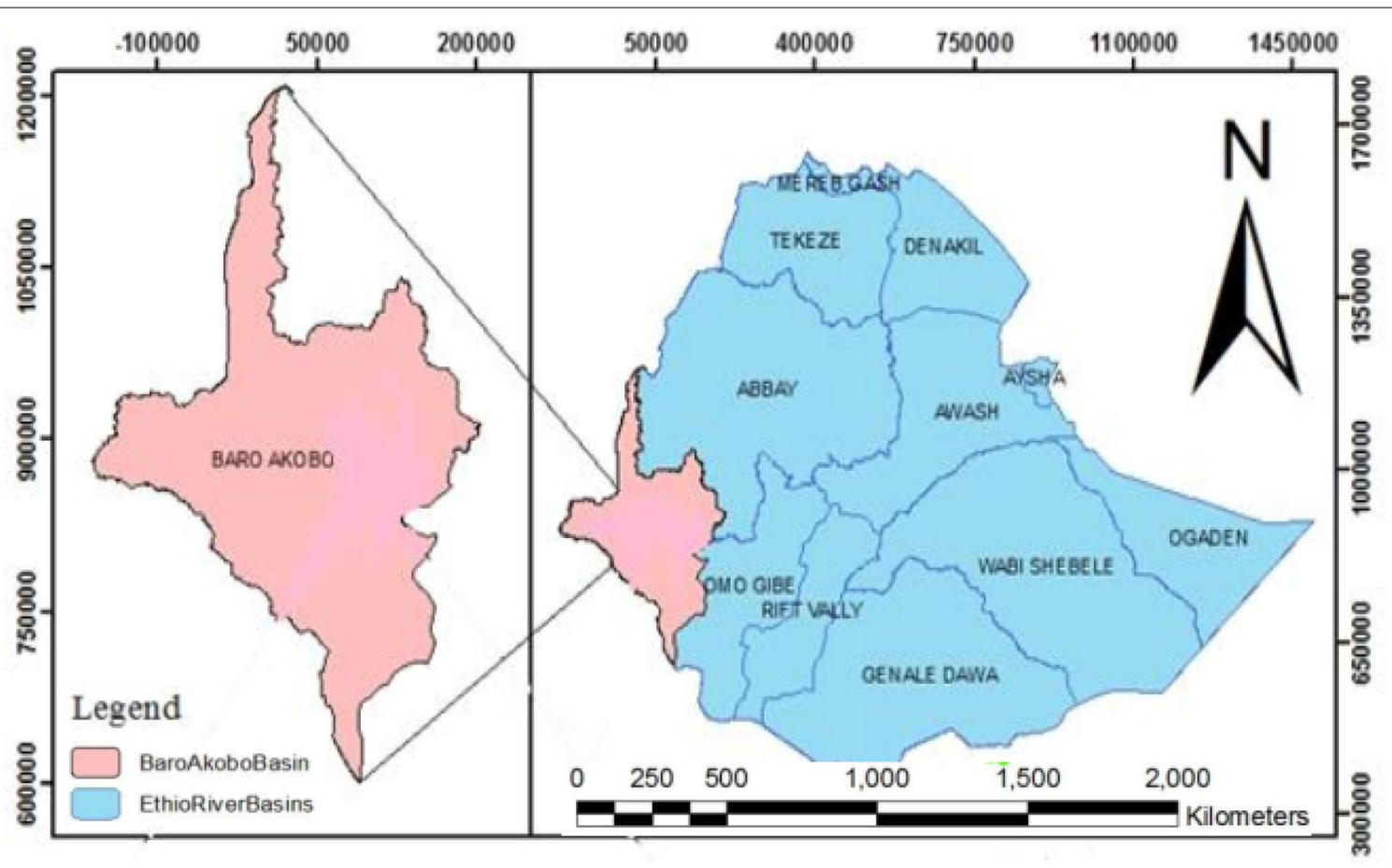

Fig. 1 Location map of Baro-Aakobo river basin relative to Ethiopian river basins

where $R_{i}$ is the rainfall measurement at $n$ rain gauges; $a_{i}$ is polygon area; $\mathrm{w}_{\mathrm{i}}$ is gauge areal weight and $\mathrm{A}$ is the total area of the catchment.

\section{Potential evapotranspiration}

Many empirical or semi-empirical equations have been developed for assessing reference/potential evapotranspiration from meteorological data. Numerous researchers have analyzed the performance of the various calculation methods for different locations. As a result of an Expert Consultation held in May 1990, the FAO Penman-Monteith method is now recommended as the standard method for the definition and computation of the potential evapotranspiration when the standard meteorological variables including air temperature, relative humidity and sunshine hours are available (Allen et al. 1998).

In this study, the Potential evapotranspiration is calculated by ETO calculator software that uses the relatively accurate and consistent performance of the PenmanMonteith approach in both arid and humid climates. ETo for the basin is determined based on the four basic climatic data-temperature $\left(\mathrm{T}_{\text {max }}, \mathrm{T}_{\text {mean }}\right.$ and $\left.\mathrm{T}_{\text {min }}\right)$, mean relative humidity, wind speed at $2 \mathrm{~m}$ above soil surface and the actual sunshine duration.

The FAO Penman-Monteith equation (Allen et al. 1998)) is given by:

$$
\boldsymbol{E} \boldsymbol{T}_{\boldsymbol{o}}=\frac{0.408 \Delta\left(\boldsymbol{R}_{\boldsymbol{n}}-\boldsymbol{G}\right)+\boldsymbol{\gamma} \frac{900}{\boldsymbol{T + 2 7 3}} \boldsymbol{u}_{2}\left(\boldsymbol{e}_{\boldsymbol{s}}-\boldsymbol{e}_{\boldsymbol{a}}\right)}{\Delta+\boldsymbol{\gamma}\left(1+0.34 \boldsymbol{u}_{2}\right)}
$$

where $\mathrm{ETo}=$ reference evapotranspiration $\left[\mathrm{mm} \mathrm{day}^{-1}\right]$, $R_{n}=$ net radiation at the crop surface $\left[M J \mathrm{~m}^{-2}\right.$ day $\left.^{-1}\right]$,

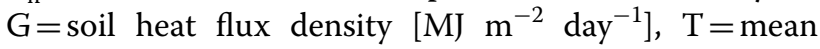
daily air temperature at $2 \mathrm{~m}$ height $\left[{ }^{\circ} \mathrm{C}\right], \mathrm{u}_{2}=$ wind speed at $2 \mathrm{~m}$ height $\left[\mathrm{m} \mathrm{s}^{-1}\right], \mathrm{e}_{\mathrm{s}}=$ saturation vapour pressure $[\mathrm{kPa}], \mathrm{e}_{\mathrm{a}}=$ actual vapour pressure $[\mathrm{kPa}], \mathrm{e}_{\mathrm{s}}-\mathrm{e}_{\mathrm{a}}=$ saturation vapour pressure deficit $[\mathrm{kPa}], \Delta=$ slope vapour pressure curve $\left[\mathrm{kPa}{ }^{\circ} \mathrm{C}^{-1}\right], \gamma=$ psychrometric constant $\left[\mathrm{kPa}{ }^{\circ} \mathrm{C}^{-1}\right]$.

\section{Baseline climate}

Baseline climate information is important to characterize the prevailing conditions and its thorough analysis is valuable to examine the possible impacts of climate change on a particular exposure unit. It can also be used as a reference with which the results of any climate change studies can be compared. The choice of baseline period has often been governed by availability of the required climate data. According to World Meteorological Organization (WMO), the baseline period also called reference period generally corresponds to the current 30 years normal period. A 30-year (1989-2018) period is used by this study to define the average climate of the basin, and scenarios of climate change are also generally based on 30-years' means. 


\section{RCM data}

Regional grid climate data that has been dynamically downscaled by RCM Version 3.1 from general Circulation model (GCM) for A1B emission scenario was obtained from International Water Management Institute (IWMI). These are gridded meteorological time-series data of precipitation; maximum, mean, and minimum temperature; wind speed; relative humidity; and potential evapotranspiration at a grid center point (GCP) spatial resolution of $0.5^{\circ}$ by $0.5^{\circ}$ (i.e., $55 \mathrm{~km}$ by $55 \mathrm{~km}$ ). GCPs that can have possible effect and fall in or nearby the basin are selected for the study. The data cover 3-periods: base (control) period (2001-2010), mid-term forecast (2040s i.e., 2041-2050) and long-term forecast (2090s i.e., 2091-2100) meteorological time-series RCM data. These data are bias corrected based on bias correction factors developed between means of observed base period data (1989-2018) and RCM base period data (2001-2010) before making use of them for mid-term and long-term scenario development.

\section{Bias correction for RCM output}

This method is used to 'adjust' the mean, variance and/or distribution of RCM climate data. All models have inadequacies due to such factors as resolution, differing internal dynamics, and model parameterizations, so different climate models can respond differently to the same inputs
(Robert and Colin 2007). Bias correction is usually needed as climate models often provide biased representations of observed times series due to systematic model errors caused by imperfect conceptualization, discretization, and spatial averaging within grid cells. Typical biases are the occurrence of too many wet days with low-intensity rain or incorrect estimation of extreme temperature in RCM simulations (Ines and Hansen 2006). A bias in RCM-simulated variables can lead to unrealistic hydrological simulations of river runoff. Thus, application of bias-correction methods is recommended (Wilby et al. 2000).

The term 'bias correction' describes the process of scaling climate model output to account for systematic errors in the climate models. The basic principle is that biases between simulated climate time series and observations are identified and then used to correct both control and scenario runs. The main assumption is that the same bias correction applies to control and scenario conditions. Several techniques are available to create an interface for translating RCM output variables to hydrological models. For instance, precipitation and temperature can be bias corrected by applying one of the following methods: Precipitation threshold, Scaling approach, linear transformation, Power transformation, Distribution transfer, Precipitation model and Empirical correction methods (Fig. 2).

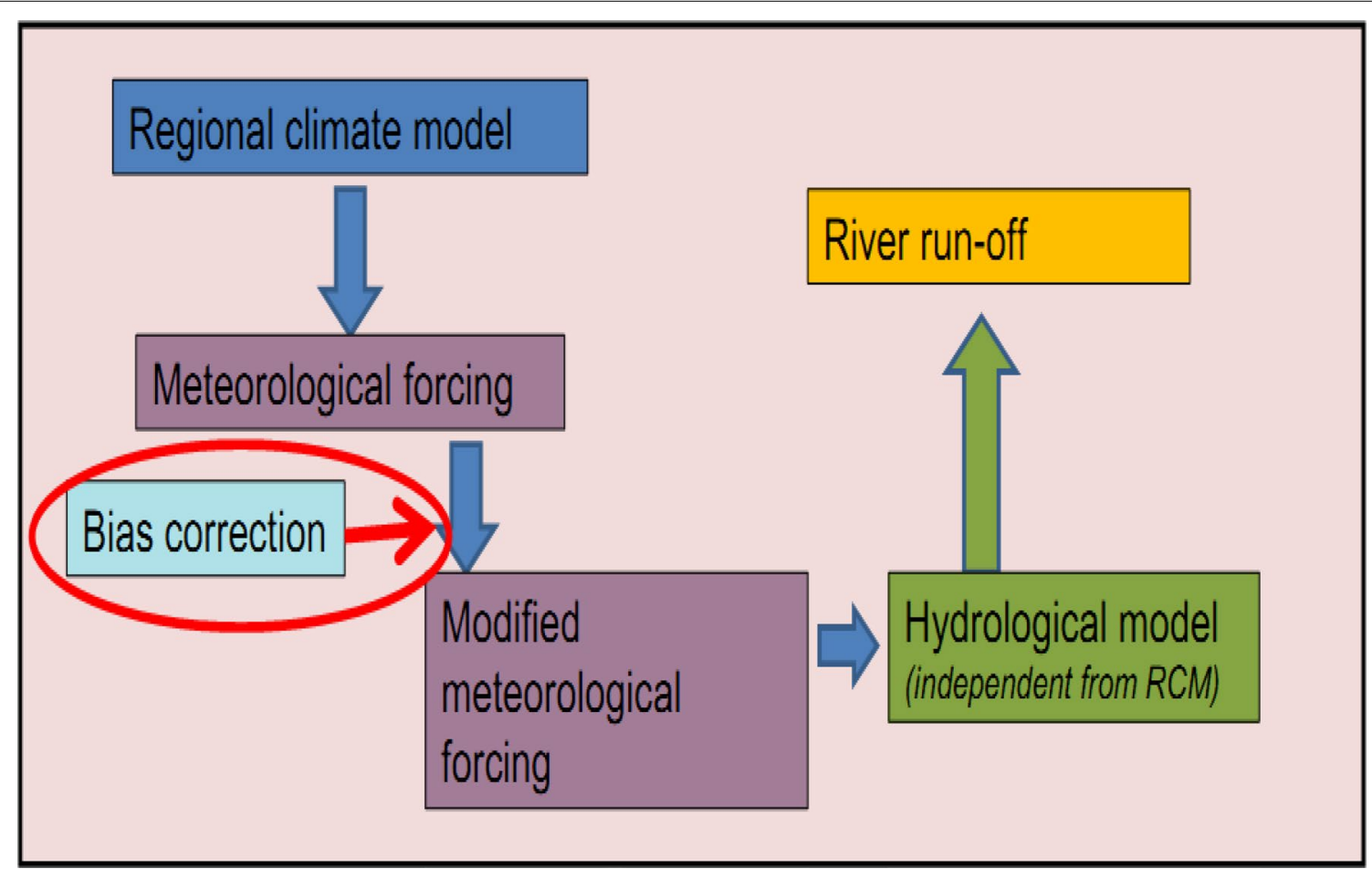

Fig. 2 Conceptual framework for bias correction 
In this work a Power Transformation method of bias correction is applied for precipitation whereas linear transformation method is used to correct temperature. In each case of bias correction attempt is made to match the most important statistics (coefficient of variation, mean and standard deviation) on a scale of 30 days.

\section{Precipitation bias correction: power transformation method}

The method is selected based on its relative simplicity and application result as used by (Leander and Buishand 2007) for a Meuse basin study. They found that adjusting both the biases in the mean and variability, the method leads to a better reproduction of observed extreme daily and multi-day precipitation amounts than the commonly used linear scaling correction.

In this nonlinear correction each daily precipitation amount $\mathrm{P}$ is transformed to a corrected $\mathrm{P} *$ using:

$$
P^{*}=a * P^{b}
$$

The impact of sampling variability is reduced by determining the parameters $a$ and $b$ for every month period of the year, including data from all years available (Leander and Buishand 2007). The determination of the $b$ parameter is done iteratively. Here the "Goal Seek" function in the Microsoft excel served the purpose. It was determined such that the coefficient of variation $(\mathrm{CV})$ of the corrected daily precipitation matches the $\mathrm{CV}$ of the observed daily precipitation. With the determined parameter " $b$ ", the transformed daily precipitation values are calculated using:

$$
P^{*}=P^{b}
$$

Then the parameter "a" is determined such that the mean of the transformed daily values corresponds with the observed mean. At the end, each block of 30 days has got its own "a" and "b" parameters, which are the same for each year.

Temperature bias correction: linear transformation method The correction of temperature only involves shifting and scaling to adjust the mean and variance (Leander and Buishand 2007). Hence, for correcting the daily temperature a linear transformation technique is applied. For the basin, the corrected daily temperature $\mathrm{T}_{\text {corr }}$ was obtained as:

$$
T_{\text {corr }}=a T_{u n}+b
$$

where $T_{u n}$ is the uncorrected daily temperature for the base period (2000s) of RCM data, and a and b are linear constants. The values of $\mathrm{a}$ and $\mathrm{b}$ are determined using the
"Goal Seek" iteration technique of MS Excel so that the statistics (mean and standard deviation) of the observed data corresponds with that of the corrected base period RCM data.

\section{Result}

Bias correction of RCM output climatic variables Bias correction factors- $a$ and $b$

As thoroughly explained under methods section above, bias correction factors a and b were developed by matching the statistical parameters (mean, coefficient of variation and standard deviation) of the observed and downscaled base period precipitation and temperature data. Values of $a$ and $b$ were determined for each month block of a year to minimize the temporal variation impact on the bias correction and these values were applied to correct each corresponding month of the mid-term (2040s) and the long-term (2090s) A1B scenario RCM data. Below is tabular summary for "a" and " $b$ " values developed for each month (Table 2).

\section{Comparison between bias corrected and uncorrected RCM output data}

Comparison was made among bias corrected RCM, uncorrected RCM and observed data to show the inherited biases in RCM on one hand and to validate the effectiveness of the factors $a$ and $b$ on the other hand. The comparisons are shown below with illustrative figures for precipitation (Fig. 3), for maximum temperature (Fig. 4) and for minimum temperature (Fig. 5).

Furthermore, it can be observed from Fig. 3 that the RCM and hence GCM has mainly underestimated the precipitation over the basin in all months except in the month of November. In the contrary, the regional climate model has generally overestimated the maximum temperature in all the months (Fig. 4). Figure 5 shows that the model overestimated minimum temperature except for months of November, December, and January. These biases in the model are attributed to poor resolution to address the local forcing.

\section{Climate change scenario}

In this study, the future climate change scenarios for the 2040s and the 2090s were assessed in comparison with the base period of the 2000s for three climatic variables - temperature, precipitation, and evapo-transpiration as presented below:

\section{Temperature scenario}

Both the projected maximum and minimum temperatures have generally shown an increasing trend for A1B 
Table 2 Tabular values of correction factors (a and b) used for bias correction

\begin{tabular}{|c|c|c|c|c|c|c|c|}
\hline \multirow[t]{2}{*}{ Block/month } & \multicolumn{2}{|l|}{ Rainfall } & \multicolumn{2}{|c|}{ Max. temperature } & \multicolumn{2}{|c|}{ Min. temperature } & \multirow[t]{2}{*}{ Remark } \\
\hline & A & $b$ & a & $b$ & a & $\mathrm{B}$ & \\
\hline 1 & 0.8792 & 1.3772 & 1.2805 & -10.6803 & 0.8133 & 2.3622 & Applied to 2040s \& 2090s, too \\
\hline 2 & 1.3542 & 1.3361 & 0.8748 & 0.9254 & 0.8411 & 1.5618 & Applied to 2040s \& 2090s, too \\
\hline 3 & 1.1954 & 1.0213 & 1.1135 & -5.7307 & 0.8486 & 1.5090 & Applied to 2040 s \& 2090 s, too \\
\hline 4 & 1.2072 & 1.0392 & 0.8521 & 0.9649 & 1.1131 & -2.3814 & Applied to 2040s \& 2090s, too \\
\hline 5 & 1.5849 & 0.8936 & 0.9328 & -0.6110 & 0.8698 & 1.3467 & Applied to 2040s \& 2090s, too \\
\hline 6 & 1.7855 & 0.8545 & 0.9972 & -2.0092 & 1.6076 & -9.1064 & Applied to 2040s \& 2090s, too \\
\hline 7 & 1.4089 & 0.8847 & 0.9127 & 0.0313 & 2.2550 & -18.3513 & Applied to 2040s \& 2090s, too \\
\hline 8 & 1.8901 & 0.7863 & 0.7631 & 3.4377 & 0.8719 & 1.0104 & Applied to 2040s \& 2090s, too \\
\hline 9 & 1.2814 & 0.9810 & 0.8754 & 1.0238 & 0.6479 & 4.2501 & Applied to 2040s \& 2090s, too \\
\hline 10 & 0.9410 & 1.1642 & 0.6818 & 5.6713 & 0.5023 & 6.3036 & Applied to 2040s \& 2090s, too \\
\hline 11 & 0.6113 & 1.2509 & 0.5312 & 9.9613 & 0.3738 & 7.9866 & Applied to 2040s \& 2090s, too \\
\hline 12 & 1.4676 & 1.3667 & 0.8765 & 0.9123 & 0.2509 & 9.2255 & Applied to 2040s \& 2090s, too \\
\hline
\end{tabular}

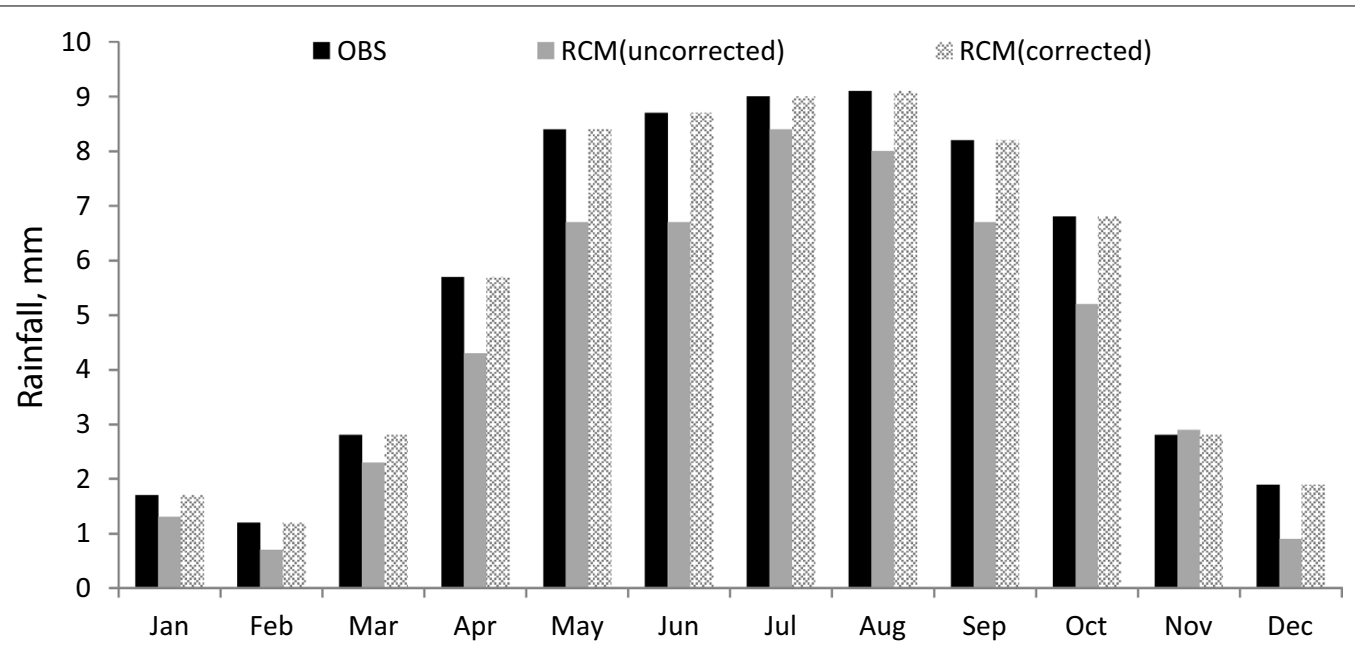

Fig. 3 Comparison of bias corrected and uncorrected RCM precipitation data on the monthly basis

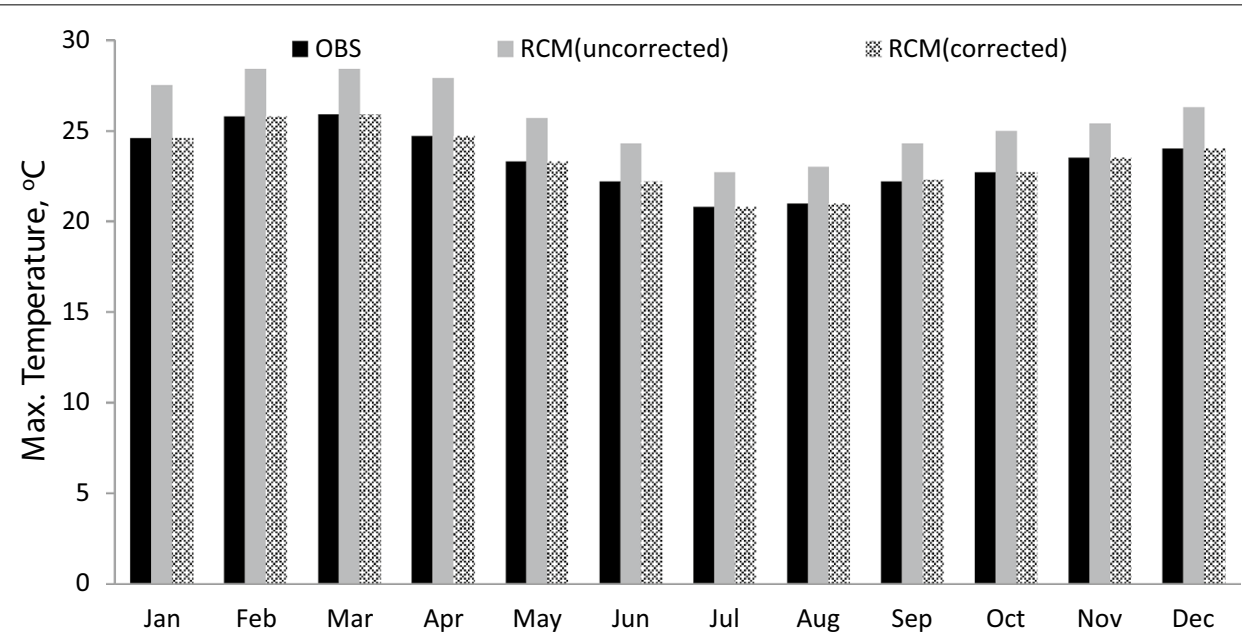

Fig. 4 Comparison of bias corrected and uncorrected RCM data of maximum temperature on the monthly basis 


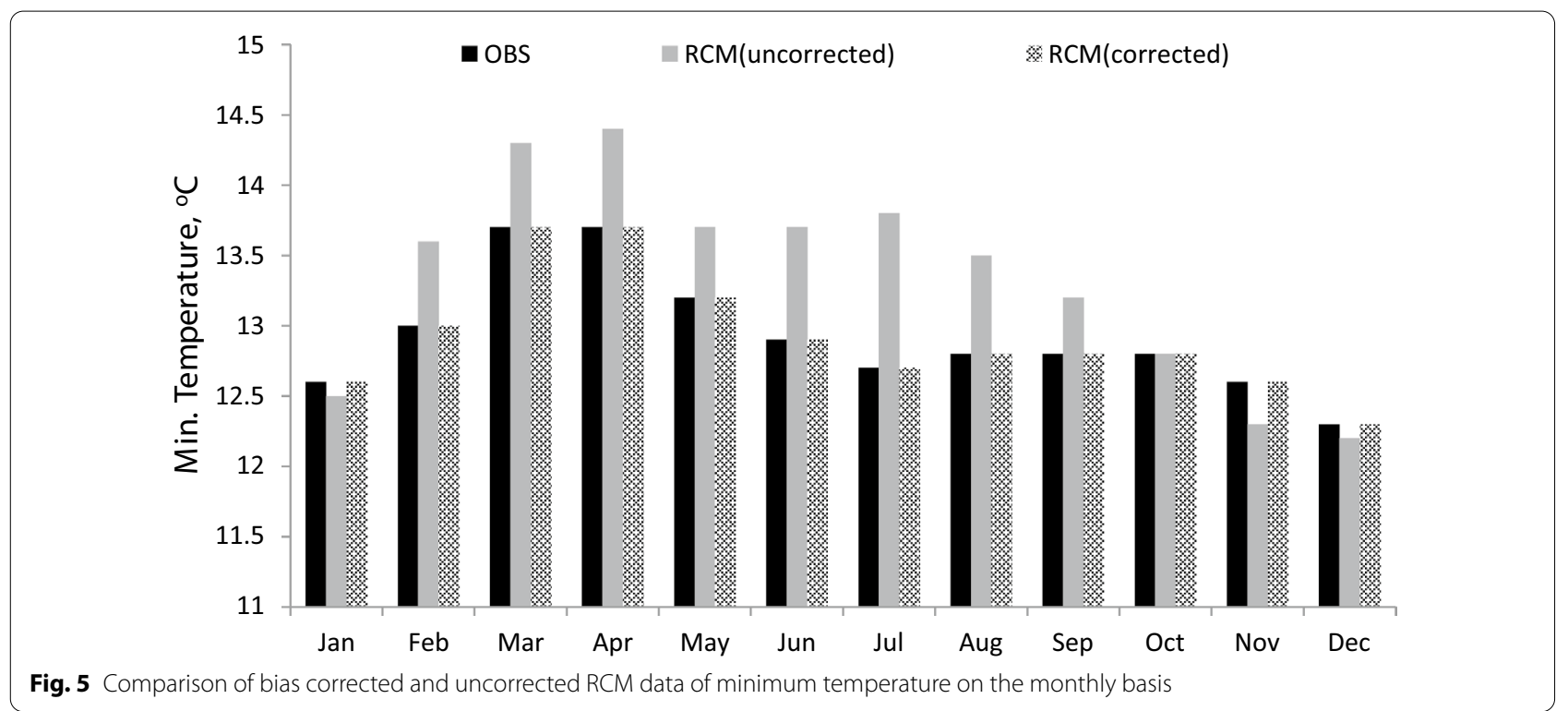

emission scenario in both future time of 2040s and 2090s (Fig. 6). Future projected maximum temperatures show large temperature fluxes in the month of January both for 2040s and 2090s forecasts with a temperature rise of $2.5{ }^{\circ} \mathrm{C}$ and $5.1{ }^{\circ} \mathrm{C}$ respectively as compared to the base period. On the other hand, minimum temperature flux will be higher in the month of July for both mid-term and long-term forecasts with a temperature rise of $2.5^{\circ} \mathrm{C}$ and $5.8^{\circ} \mathrm{C}$ respectively (Fig. 7). Generally, the projected mean annual temperature increases from the baseline period by an amount of $1{ }^{\circ} \mathrm{C}$ and $3.5{ }^{\circ} \mathrm{C}$ respectively, in 2040s and 2090s. This implies that temperature will continue to increase in the twenty first century over the basin.

\section{Precipitation scenario}

In contrast to temperature, projection of rainfall does not manifest a systematic increase or decrease in the coming time horizon for A1B global emission scenario (Figs. 8, $9,10)$. It shows a decreasing trend in the mid-term projection (Fig. 9) and an increasing trend for 2090s projection (Fig. 10). This contrasting trend implies the fact that rainfall probability and frequency over a given area will be shifted spatially and temporally following change in the climate. Precipitation experiences a mean annual decrease of $1.8 \%$ by 2040 s and an increase of $1.8 \%$ in 2090s over the basin for the A1B emission scenario.

However, future projection of rainfall depicts a considerable change on seasonal and monthly basis. For instance, the rainfall will experience a reduction of up to $29 \%$ in January and rises to $42 \%$ in February for future 2040 s projection. Likewise, a precipitation decreases of up to $24 \%$ in January and a rise of up to $47 \%$ in December was predicted for the 2090s A1B global emission scenario as can be observed from Fig. 11.

Moreover, one can observe considerable seasonal variation in precipitation change with increasing trend in the rainy season (July to December) and a decreasing trend in the dry season (January to May), Fig. 11. This has an implication climate change on the intensification of hydrologic extremes-drought and flooding in the future.

\section{Evapo-transpiration scenario}

Relative to the current condition, the average annual evapo-transpiration over the basin shows increasing trends in both short-term (2040s) and long-term (2090s) forecasts for the A1B scenario (Fig. 12). According to this study, evapotranspiration has been found to increase to an extent of $25 \%$ in the month of July (Fig. 13). Seasonal wise, it can be observed that considerable evapotranspiration fluxes are projected in summer season for the 2090s and relatively little monthly and seasonal variation is depicted in evapotranspiration of 2040s prediction. The result shown is so logical in the sense that evapotranspiration will be favored by increased water surface coverage (in summer) and by the increasing temperature to the end of the century.

\section{Discussion}

The current issue of climate change adaptive strategy in the water resources sector can be achieved through the characterization of climate-related risks and response options to climate change under different socio-economic futures and development prospects are essential for sustainable water resources management 
Muleta Environ Syst Res

(2021) 10:24

Page 10 of 15

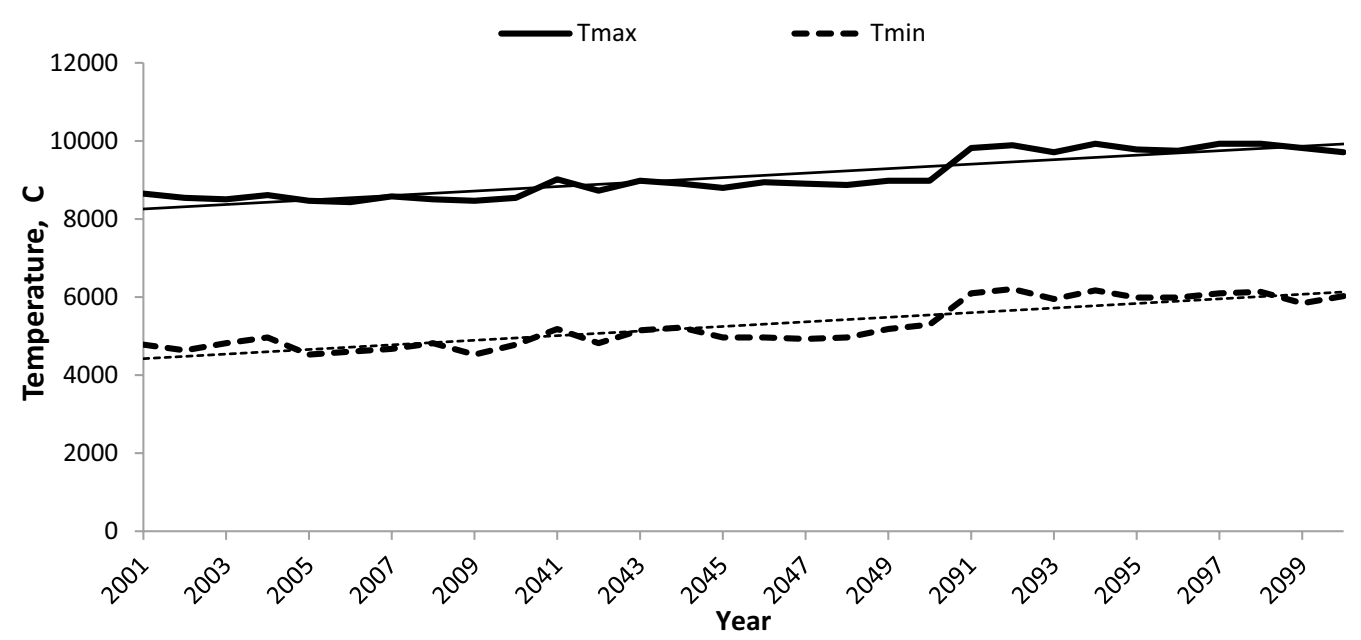

Fig. 6 Projected maximum and minimum annual temperature trends

-Tmax-2040s $=$ Tmin-2040s $\square$ Tmax-2090s $\cong$ Tmin-2090s

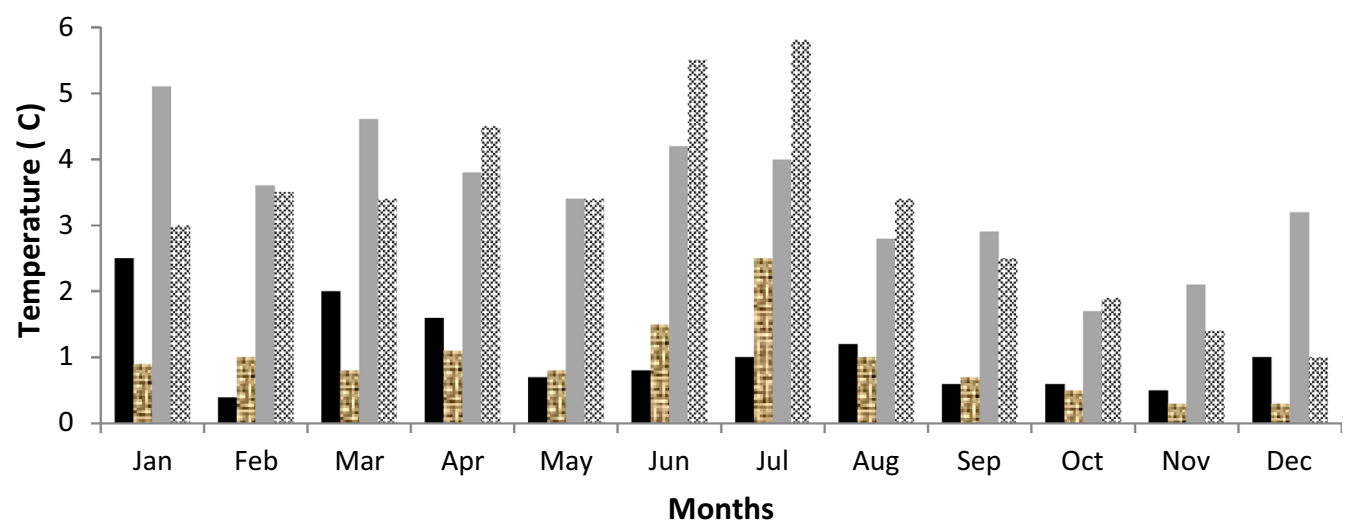

Fig. 7 Future mean monthly max. and min. temperature fluxes compared to base period

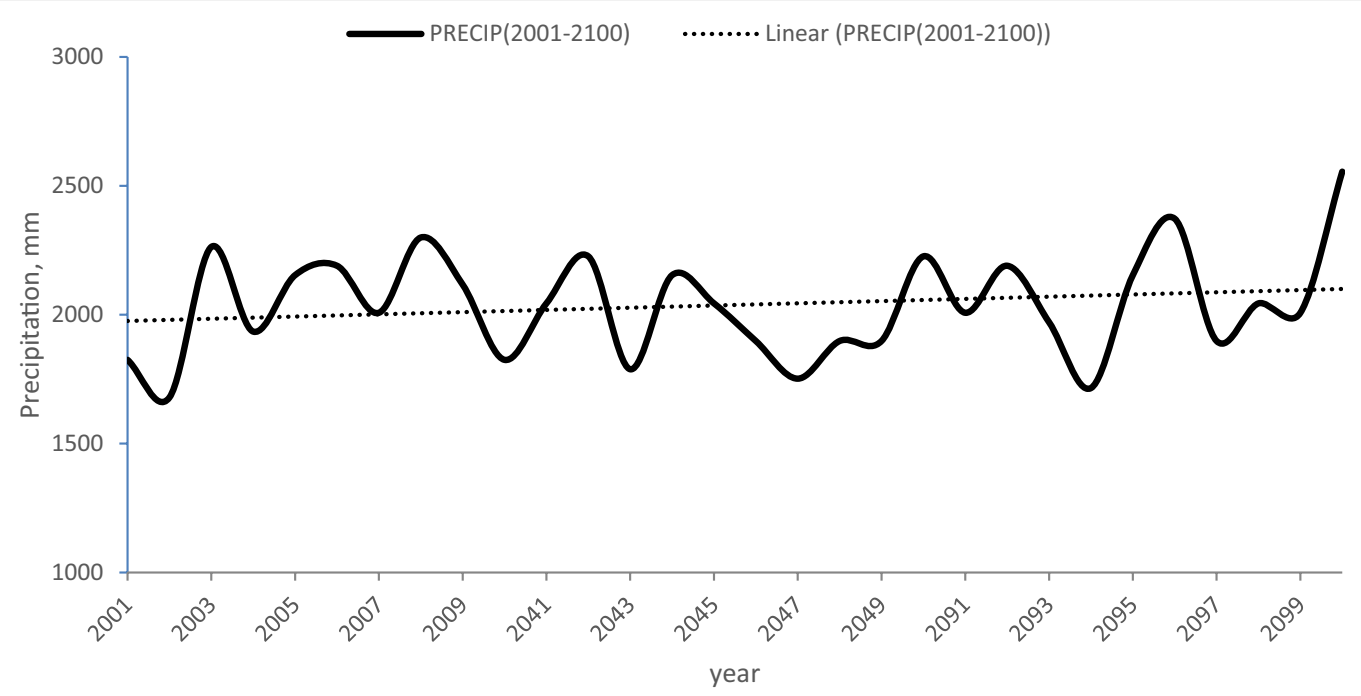

Fig. 8 Annual precipitation trend in general (2001 through 2100) for A1B scenario 


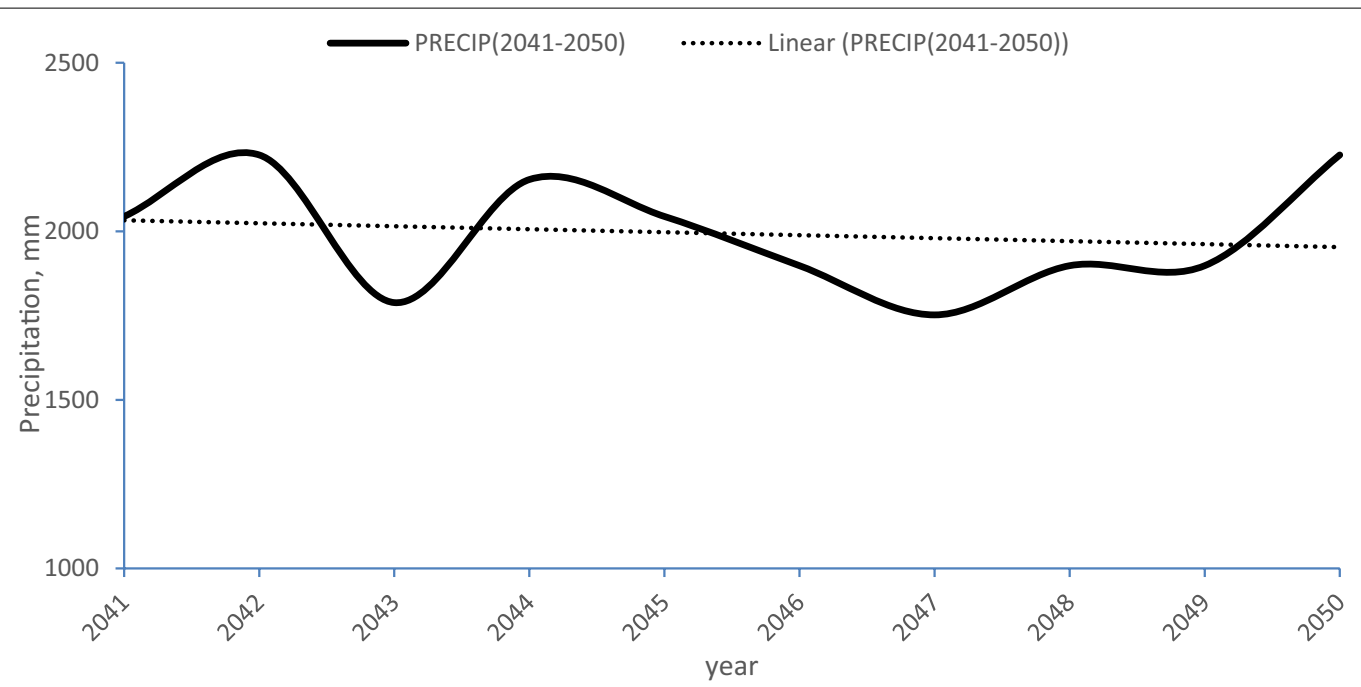

Fig. 9 Projected annual precipitation trend in the mid-term (2041-2050) for A1B scenario

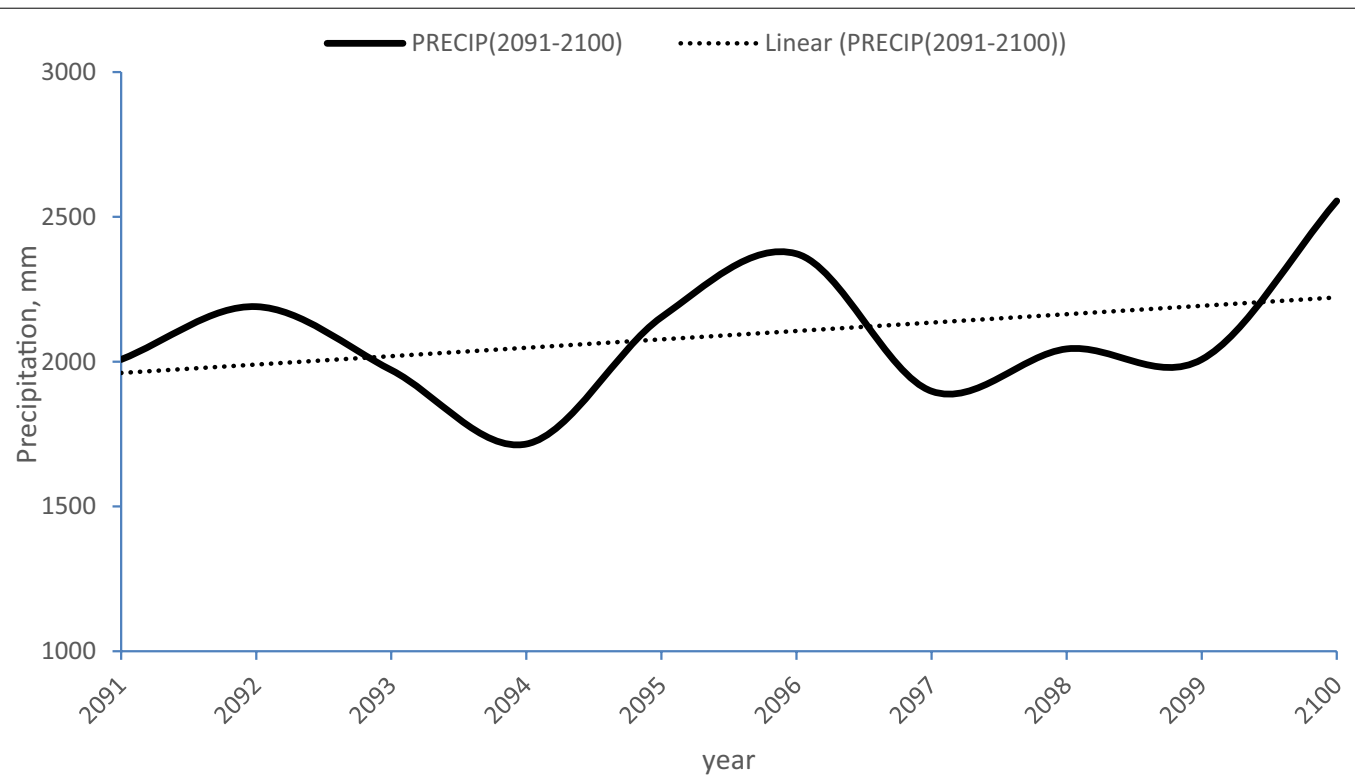

Fig. 10 Projected annual precipitation trend in the long-term (2091-2100) for A1B scenario

(Cradock-Henry et al. 2018). This can be achieved through relevant climate change scenarios development at the national and local scales for sustainable development and management of projects and programs across relevant sectors (Aparecido et al. 2020; Poonia and Rao 2018; Aziz et al. 2020). The current study has laid a baseline information for climate change adaptive strategies and water resources management decision support.

The projected maximum and minimum temperature shows an increasing trend for the next century, which is obviously attributed to the increasing emission scenario of GHG. But, on the contrary, Precipitation prediction does not manifest a general trend in the future scenarios; rather it depicts a slightly decreasing trend in the midterm forecast (2040s) and an increasing trend in the late century (2090s) for the A1B emission scenario. Typically, projection of rainfall has shown a large seasonal variation-a considerable increase in summer and autumn with reduction in winter and spring (Fig. 11). This variation accompanied by highly increasing evapotranspiration in the future climate will have a clear implication of a likely occurrence of hydrologic extremes-drought and flooding-over the basin. 


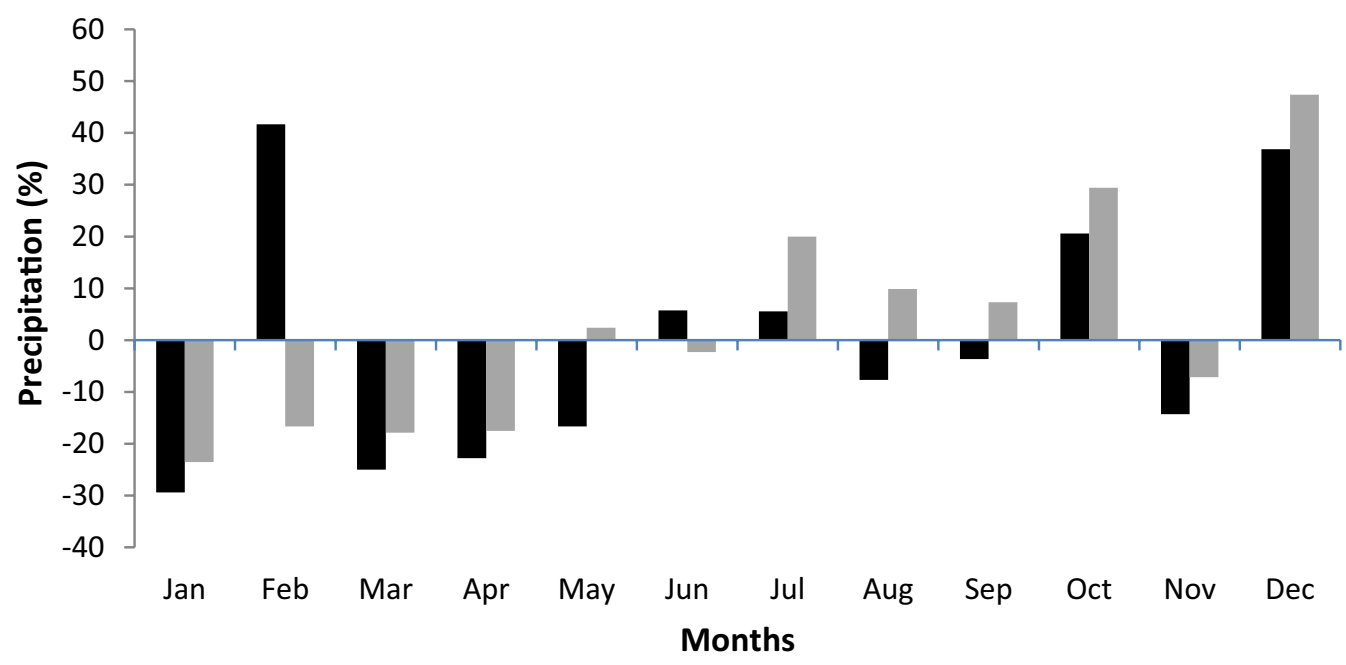

Fig. 11 Percentage monthly projected precipitation changes compared to the base period

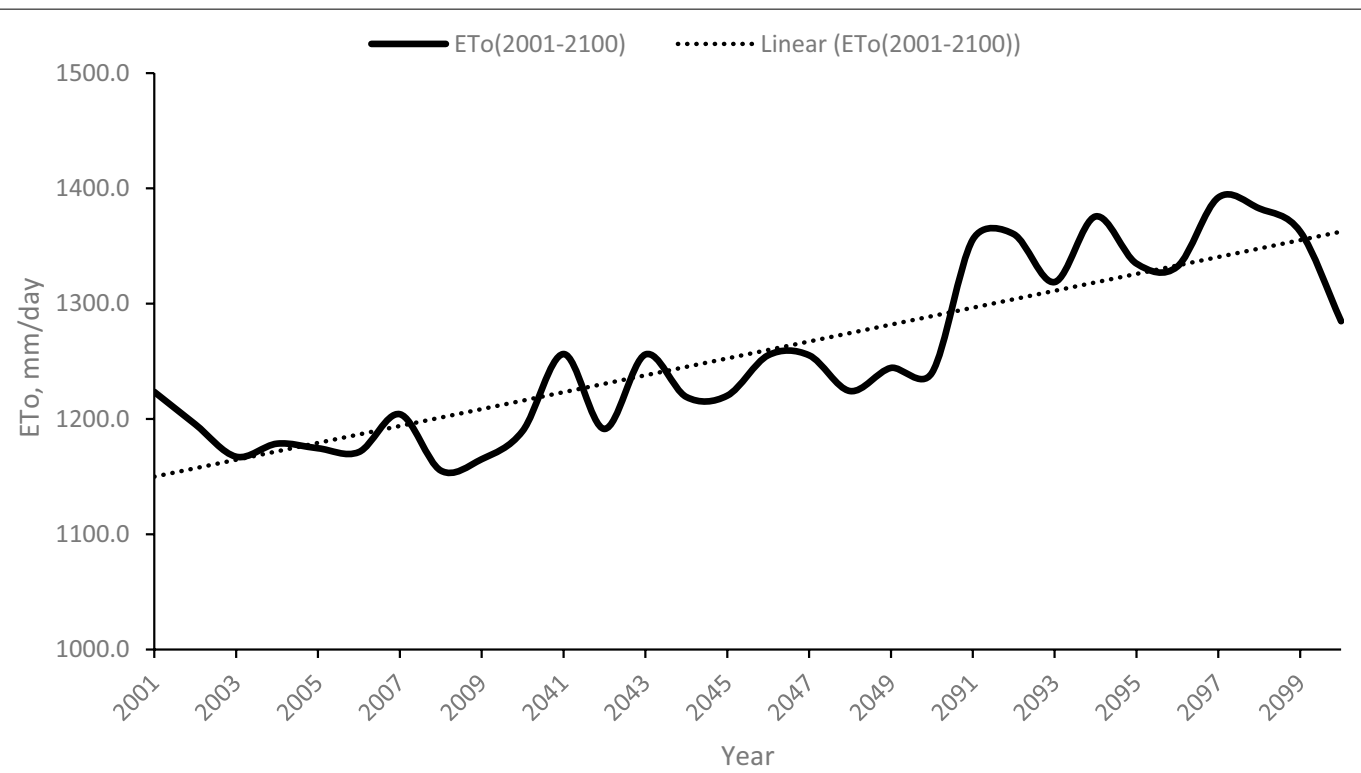

Fig. 12 Mean annual evapotranspiration trend for A1B emission scenario

The results shown related to bias correction indicates that still considerable biases inherited from GCM are prevailing in the RCM outputs. Studies have shown that Global climate models (GCMs) are inherently unable to present local subgrid-scale features and dynamics (David and José 2014) and consequently climate change studies at local level are required for decision makers. Bastien (2017). Furthermore, it is an indication of a poor representation of the regional or continental level climate change scenario at the basin level. These variations and biases in the model outputs are of course expected owed to locally sensitive climatic variables and complexity of the global system, in which case GCM and even RCM are inherently unable to represent local sub grid-scale features and dynamics at basin levels.

The current study outputs of climate change on the basin shows a good agreement with previous studies such as Carvalho et al. (2017), Costa et al. (2019), Hany et al. (2016), Myo and Zin (2020), Roth et al. (2018), and Xueping et al. (2018) (Table 1) as far as temperature 


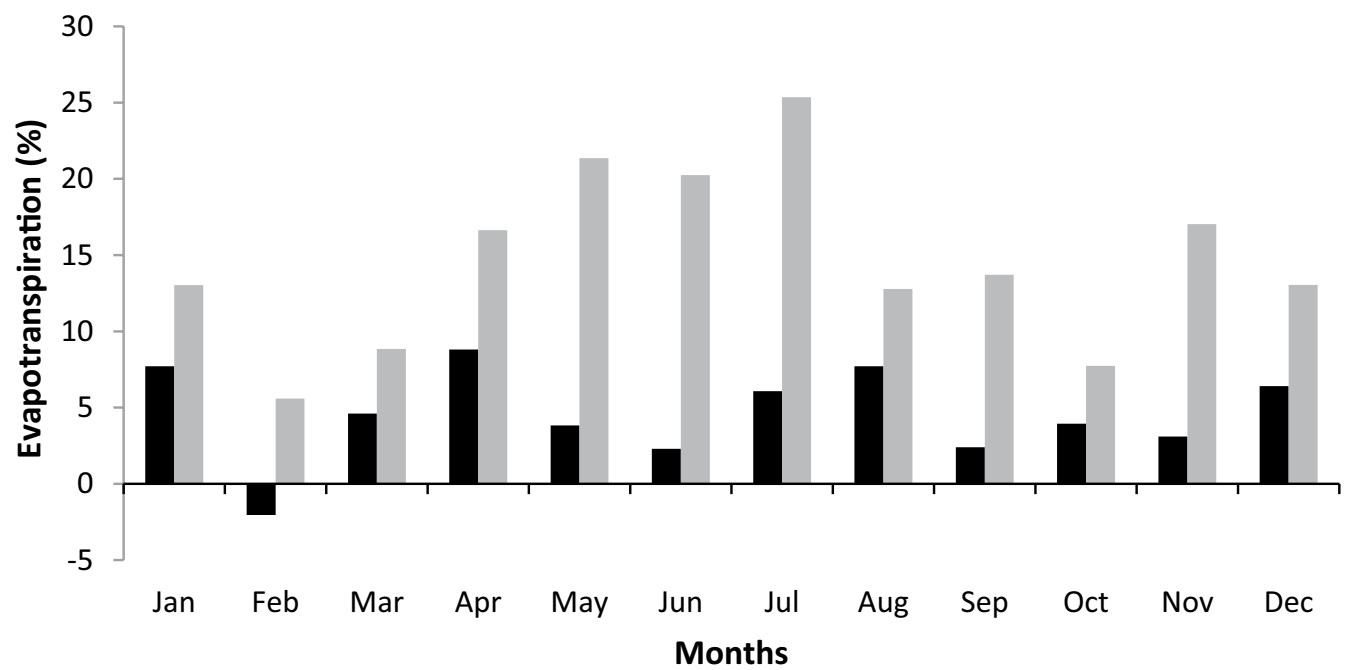

Fig. 13 Percentage changes in the projected evapotranspiration as compared to the base period

change scenario is considered. Moreover, the current projected mean annual temperature changes of $3.5^{\circ} \mathrm{C}$ in 2090s is within the range projected by (IPCC 2018) which indicated that the average temperature rise to be in the range of $1.4-5.8^{\circ} \mathrm{C}$ towards the end of this century. But in the case of precipitation change scenario, the results do not show consistency and of course this is true also with the previous studies and we can say that the result showed a good agreement with the studies in behavior rather than quantitatively (refer to Table 1 ).

The inconsistency in the rainfall change scenario among the studies is attributed to the sensitivity of rainfall variable to the poor resolutions of GCM (Myo and Zin 2020), differences in the models (Costa et al. 2019), and local factors such as orographic, coastal and vegetation effects (Jose et al. 2016; David and José 2014). Of course, this is the central reason to have conducted the current study in addition to the peculiar features of the basin such as distinctive bimodal rainfall pattern and the vast water resources developments. To this end, bias correction is employed in the current study (which, of course, lacks in the previous studies) to better account for the local effects than directly using the downscaled meteorological data as in the case of previous studies. However, the current study is limited to a single alternative scenario- $\mathrm{A} 1 \mathrm{~B}$, with the objective of getting single valued average climate scenarios. In fact, the probability of a single-story line to occur in the future is highly limited. Therefore, further studies can be extended using the other alternative scenarios and models to show the range of climate change scenarios over the basin. The research needs also to be extended to the other basins of the country.

\section{Conclusions}

The result of climate projection reveals significant climate change scenarios over Baro-Akobo basin particularly in terms of monthly and seasonal distribution with the implication of hydrologic extremes. This, accompanied with the extensive water resources development projects in the basin and its transboundary environmental effect, calls for climate change adaptive strategies and real-time water resources managements. Therefore, the obtained result produced a baseline data that support adaptation of the vast water resources development planning and management in the basin to the ever-changing climate. The author highly recommends researchers to model the relation between these climate change scenarios and reservoir inflows as climate change adaptation strategy. It further helps reservoir operators to modify their operation rules to better combat hydrologic extremes and minimize the possible environmental impacts of the vast water resources developments on the local and downstream Nile basin countries.

However, the study has involved several models' outputs where each possessed a certain level of uncertainty. Moreover, it is based on a single emission scenario storyline (A1B). Hence, the results of this study should be taken with care and be considered as indicative of the likely future rather than accurate predictions. It is believed that the results of this study give a baseline data 
and increase awareness on the possible future risks of climate change.

\begin{abstract}
Abbreviations
AOGCMs: Atmosphere-Ocean General Circulation Models; CV: Coefficient of Variation; DEM: Digital Elevation Model; ETo: Reference Evapotranspiration; FAO: Food and Agricultural Organization; GCM: Global Climate Model; GCP: Grid Center Point; GHG: Greenhouse Gas; HEC-GeoHMS: Hydrologic Engineering Center Geospatial Hydrologic Modeling System; IWMI: International Water Management Institute; IPCC: Intergovernmental Panel for Climate Change; LAMs: Limited area models; MAP: Mean Areal Precipitation; MoWR: Ministry of Water Resources; NMA: National Meteorological Agency; NAPA: National Adaptation Programme of Action; Obs: Observed; SRES: Special Report on Emission Scenario; RCM: Regional Climate Model; WMO: World Meteorological Organization.
\end{abstract}

\section{Acknowledgements}

It is my pleasure to express my special heartfelt thanks and appreciation to my advisor Dr. Knolmar Marcell, an Assistant Professor at the Department of Sanitary and Environmental Engineering, Budapest University of Technology and Economics, Budapest, Hungary for his valuable support in draft review and editing of the manuscript and his all-round advisory support. I would like to extend my gratitude to Dr. Solomon Seyoum, a director general for International Water Management Institute at Ethiopia for his excellent support in providing GCM data and his guidance on how to bias correct the data. I am also highly indebted to all organizations and Institutes those provided me with important data \& materials mainly Ministry of Water and Energy, National Metrological Agency, and International Water Management Institute.

\section{Authors' contributions}

TN performed all the conceptualization, study design, statistical analysis of results, data interpretation, and writing the manuscript. The author read and approved the final manuscript.

\section{Funding}

This study was not funded by any grant.

\section{Availability of data and materials}

The datasets used and/or analyzed during the current study are included as much as possible and available from the corresponding author up on request.

\section{Declarations}

\section{Ethics approval and consent to participate}

Not applicable.

\section{Consent for publication}

Not applicable.

\section{Competing interests}

The author declares that there is not any competing interest.

Received: 13 November 2020 Accepted: 22 February 2021

Published online: 26 March 2021

\section{References}

Alemayehu T, Kebede S, Liu L, Nedaw D (2016) Groundwater recharge under changing landuses and climate variability: the case of Baro-Akobo River Basin, Ethiopia. J Environ Earth Sci 6(1):78-95

Allen RG, Pereira LS, Raes D, Smith M (1998) Crop evapotranspiration-Guidelines for computing crop water requirements-FAO Irrigation and drainage paper 56. Fao, Rome 300(9):D05109

Anthes RA, Kuo YH, Baumhefner DP, Errico RM, Bettge TW (1985) Predictability of mesoscale atmospheric motions. Adv Geophys 28:159-202
Aparecido LEO, José RSCM, Kamila CM, Pedro AL, João AL, Gabriel HOS, Guilherme BT (2020) Agricultural zoning as tool for expansion of cassava in climate change scenarios. Theor Appl Climatol. 142(3):1085-1095

Aziz R, Yucel I, Yozgatligil C (2020) Nonstationarity impacts on frequency analysis of yearly and seasonal extreme temperature in Turkey. Atmos Res 238:104875

Barrow E, Hulme M, Semenov M (1996) Effect of using different methods in the construction of climate change scenarios: examples from Europe. Climate Res 7(3):195-211

Bastien B (2017) Downscaling climate change signal in Mexico

Bell WP, Wild P, Froome C, Wagner LD (2013) Selecting emission and climate change scenarios: review. University of Queensland, Queensland

Brekke LD, Maurer EP, Anderson JD, Dettinger MD, Townsely ES, Harrison A, Pruitt T (2009) Assessing reservoir operations risk under climate change. Water Resour Res 45:7

Carvalho SC, Santos FD, Pulquério M (2017) Climate change scenarios for Angola: an analysis of precipitation and temperature projections using four RCMs. Int J Climatol 37(8):3398-3412

Chow V, Maidment D, Mays L (1988) Applied Hydrology then. McGraw-Hill Book Company, New York

Conde C, Estrada F, Martínez B, Sánchez O, Gay C (2011) Regional climate change scenarios for México. Atmósfera 24(1):125-140

Conway D, Hulme M (1996) The impacts of climate variability and future climate change in the Nile Basin on Water Resources in Egypt. Water Resour Develop 12(3):277-296

Costa RL, Heliofábio BG, Fabrício DSS, Rodrigo LRJ (2019) Downscale of future climate change scenarios applied to Recife-PE. J Hyperspectral Rem Sens. https://doi.org/10.1007/s00704-020-03367-1

Cradock-Henry NA, Frame B, Preston BL, Reisinger A, Rothman DS (2018) Dynamic adaptive pathways in downscaled climate change scenarios. Clim Change 150(3):333-341

Cubash U, von Storch H, Waszkewitz J, Zorita E (1996) Estimates of climate change in Southern Europe derived from dynamical climate model output. Climate Res 7:129-149

David M, José MA (2014) Neural networks for downscaling climate change scenarios

Raje D, Mujumdar PP (2010) Reservoir performance under uncertainty in hydrologic impacts of climate change. Adv Water Resour 33(3):312-326

Dickinson RE, Errico RM, Giorgi F, Bates GT (1989) A regional climate model for the western United States. Clim Change 15(3):383-422

Dickinson RE, Bougher SW (1986) Venus mesosphere and thermosphere: 1. Heat budget and thermal structure. J Geophys Res 91(A1):70-80

Feyissa G, Zeleke G, Bewket W, Gebremariam E (2018) Downscaling of future temperature and precipitation extremes in Addis Ababa under climate change. Climate 6(3):58

Mostafa H, Saleh H, El Sheikh M, Kheireldin K (2016) Assessing the impacts of climate changes on the eastern Nile flow at Aswan. J Am Sci 12(1):1-9

Hewitson BC, Crane RG (1996) Climate downscaling: techniques and application. Clim Res 7(2):85-95

Hulme M, Viner D (1998) A climate change scenario for the Tropics. Climate change (UNEP/IES), pp 145-176

Ines AV, Hansen JW (2006) Bias correction of daily GCM rainfall for crop simulation studies. Agric For Meteorol 138(1-4):44-53

IPCC (2001) Climate Change 2001: Impacts, Adaptation and Vulnerability Contribution of Working Group II to the Third Assessment Report of the IPCC. Cambridge, Cambridge University Press

IPCC (2000) Emission Scenarios: A special Report of Working Group III of the IPCC. Cambridge University Press, Cambridge

IPCC (2007) Impacts, Adaptation and Vulnerability: Contribution of Working Group II to the Fourth Assessment Report of the Intergovernmental Panel on Climate Change. Cambridge University Press, Cambridge

IPCC (2018) Special Report on the impacts of global warming of $1.5^{\circ} \mathrm{C}$ above pre-industrial levels and related global greenhouse gas emission pathways. Switzerland

Jones JA (1999) Climate change and sustainable water resources: placing the threat of global warming in perspective. Hydrol Sci J 44(4):541-557

Jose AM, Alves LM, Torres RR (2016) Regional climate change scenarios in the Brazilian Pantanal watershed. Climate Res 68(2-3):201-213 
Leander R, Buishand TA (2007) Resampling of regional climate model output for the simulation of extreme river flows. J Hydrol 332(3-4):487-496

Li L, Xu H, Chen X, Simonovic SP (2010) Streamflow forecast and reservoir operation performance assessment under climate change. Water Resour Manage 24(1):83-104

De Luca DL, Petroselli A, Galasso L (2020) A transient stochastic rainfall generator for climate changes analysis at hydrological scales in Central Italy. Atmosphere 11(12):1292

Mearns LO, Bogardi I, Giorgi F, Matyasovzky I, Palecki M (1999) Comparison of climate change scenarios generated from regional climate model experiments and statistical downscaling. J Geophys Res 104(D6):6603-6621

Mohamed H (2015) Impact of Climate Change on Water Resources in the Nile Basin and Adaptation measures in Egypt. Researchgate. https://www. researchgate.net/publication/277330599. Accessed 25 July 2020

Myo HT, Zin WW (2020) Forecasting climate change scenarios in central dry zone of Myanmar

NAPA (2007) Preparation of National Adaptation Programme of Action (NAPA) of Ethiopia. Addis Abeba

Pabitra G, Praju G (2020) Climate Change Scenarios in Nepal. Technical, Kathmandu

Poonia S, Rao AS (2018) Climate and climate change scenarios in the Indian Thar Region. Springer, Switzerland

Rahman HA (2018) Climate change scenarios in Malaysia: engaging the public. Int J Malay-Nusantara Stud 12:7

Robert K, Colin H (2007) A review of climate change and its potential impacts on water resources in the UK. Official Publication of the European Water Association (EWA), London

Roth V, Lemann T, Zeleke G, Subhatu AT (2018) Effects of climate change on water resources in the upper Blue Nile Basin of Ethiopia. Heliyon 4:e0071

Safieh J, Rebwar D, Forough J (2020) Climate change scenarios and effects on snow-melt runoff. Civil Eng J. 6:1715
Santosh N, Pradhananga S, Lutz A, Shrestha A, Arun SB (2019) Climate Change Scenarios for Nepal for National Adaptation Plan. Ministry of Forests and Environment

Schneider SH, Easterling WE, Mearns LO (2000) Adaptation: sensitivity to natural variability, agent assumptions and dynamic climate changes. Clim Change 2000(45):203-221

Smith JB, Pitts G (1997) Regional Climate change scenariosfor vulnerability and adaptation assessments. Clim Change 36:3-21

Tahani MS, ElShamy M, Mohammed AA, Abbas MS (2013) The Development of the Baro-Akobo-Sobat sub basin and its Impact on Downstream Nile Basin Countries. Nile Water Sci Eng J. 6:2

Wilby RL, Hay LE, Gutowski WJ Jr, Arritt RW, Takle ES, Pan Z, Leavesley GH, Clark MP (2000) Hydrological responses to dynamically and statistically downscaled climate model output. Geophys Res Lett 62:182

Wilby RL, Wigley TML (1997) Downscaling general circulation model output: a review of methods and limitations. Prog Phys Geogr 21(4):530-548

Xueping Z, Chi Z, Qi W, Wenjun C, Xuehua Z, Xueni W (2018) Multiple climate change scenarios and runoff response in Biliu River. Water 10:126

\section{Publisher's Note}

Springer Nature remains neutral with regard to jurisdictional claims in published maps and institutional affiliations.

\section{Submit your manuscript to a SpringerOpen ${ }^{\circ}$ journal and benefit from:}

- Convenient online submission

- Rigorous peer review

- Open access: articles freely available online

- High visibility within the field

- Retaining the copyright to your article

Submit your next manuscript at $\boldsymbol{\nabla}$ springeropen.com 